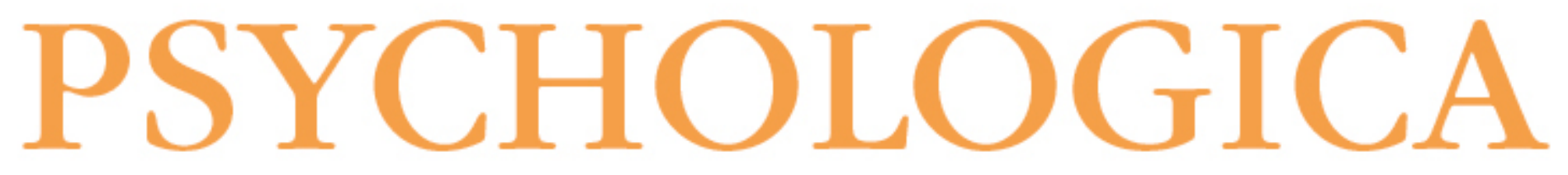

\title{
A systematic review of the transtheoretical model of behaviour change and alcohol use
}
Autor(es):
Felicíssimo, Flaviane Bevilaqua; Barros, Víviam Vargas de; Pereira, Sabrina Maura; Rocha, Natália Quintela; Lourenço, Lélio Moura

Publicado por: Imprensa da Universidade de Coimbra

URL persistente:

URI:http://hdl.handle.net/10316.2/35819

DOI:

DOI:http://dx.doi.org/10.14195/1647-8606_57_1_1

Accessed : $\quad$ 26-Apr-2023 00:45:49

A navegação consulta e descarregamento dos títulos inseridos nas Bibliotecas Digitais UC Digitalis, UC Pombalina e UC Impactum, pressupõem a aceitação plena e sem reservas dos Termos e Condições de Uso destas Bibliotecas Digitais, disponíveis em https://digitalis.uc.pt/pt-pt/termos.

Conforme exposto nos referidos Termos e Condições de Uso, o descarregamento de títulos de acesso restrito requer uma licença válida de autorização devendo o utilizador aceder ao(s) documento(s) a partir de um endereço de IP da instituição detentora da supramencionada licença.

Ao utilizador é apenas permitido o descarregamento para uso pessoal, pelo que o emprego do(s) título(s) descarregado(s) para outro fim, designadamente comercial, carece de autorização do respetivo autor ou editor da obra.

Na medida em que todas as obras da UC Digitalis se encontram protegidas pelo Código do Direito de Autor e Direitos Conexos e demais legislação aplicável, toda a cópia, parcial ou total, deste documento, nos casos em que é legalmente admitida, deverá conter ou fazer-se acompanhar por este aviso.

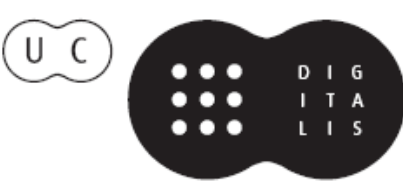


VOLUME $5 \longdiv { 2 0 1 4 }$

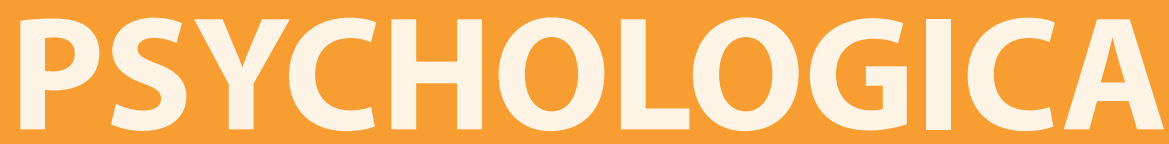

IMPRENSA DA UNIVERSIDADE DE COIMBRA

COIMBRA UNIVERSITY PRESS

FACULDADE DE PSICOLOGIA E DE CIÊNCIAS

DA EDUCAÇÃO DA UNIVERSIDADE DE COIMBRA 


\title{
A systematic review of the transtheoretical model of behaviour change and alcohol use
}

\author{
Flaviane Bevilaqua Felicíssimoㄴ, Víviam Vargas de Barros ${ }^{2}$, Sabrina \\ Maura Pereira ${ }^{3}$, Natália Quintela Rocha ${ }^{4}$ and Lélio Moura Lourenço ${ }^{5}$
}

\begin{abstract}
Issues: The study on alcohol has been increasing worldwide due to its social and economic impact, and the illnesses related to alcohol use rank among the most common substance abuse disorders. It seems necessary to further investigate the most effective and suitable treatment methods for different populations. Approach: This paper evaluated the scientific literature on the Transtheoretical Model of Behavior Change related to alcohol consumption. Scopus, Pubmed, PsycInfo, PepsiCo and Lilacs databases were consulted, using the descriptors transtheoretical model, transtheoretical approach, stages of change, processes of change and cycle of change crossed with the descriptor alcoholism, in a ten-year timeframe (2001 to 2011). Key Findings: A majority of research with longitudinal and quantitative methods was found in addition to a prevalence of Readiness to Change Questionnaire and University of Rhode Island Change Assessment usage as measuring instruments for Transtheoretical Model. The results indicated that other variables may influence the behavior of the individual in relation to his stage of change and identified alcohol-related problems in patients seeking treatment for other health conditions. This finding stresses the need for screening practices for injury prevention related to alcohol use. Implications: The Transtheoretical Model is important in the process of behaviour change, since it allows the identification of the stages and the better adapted interventions based on the patient's stage that avoids making efforts
\end{abstract}

1 Department of Psychology, Federal University of Juiz de Fora, Juiz de Fora, Brazil. Email: flavianejf@hotmail.com

2 Department of Psychology, Federal University of Juiz de Fora, Juiz de Fora, Brazil. Email: viviamvb@yahoo.com.br

3 Department of Psychology, Federal University of Juiz de Fora, Juiz de Fora, Brazil. Email: sabrina_maura@yahoo.com.br

4 Department of Psychology, Federal University of Juiz de Fora, Juiz de Fora, Brazil. Email: natyquintela@bol.com.br

$5 \mathrm{PhD}$ - Professor of the Department of Psychology, Federal University of Juiz de Fora, Juiz de Fora, Brazil. Email: leliomlourenco@yahoo.com.br 
in the opposite direction to what is demanded by the patient. Conclusion: It is worth emphasizing the need for more studies in this area especially in relation to the practice of health professionals.

Keywords: Transtheoretical Model; stages of change; alcoholism; systematic review

Uma revisão sistemática do modelo transteórico de mudança de comportamento e uso de álcool

Resumo

Introdução: $\mathrm{O}$ estudo sobre o álcool tem aumentado em todo o mundo devido ao seu impacto social e econômico, e as doenças relacionadas ao uso de álcool estarem entre os distúrbios mais comuns de abuso de substâncias. Desta forma, faz-se necessário investigar os métodos mais eficazes e adequados de tratamento para diferentes populações. Método: Este trabalho analisou a literatura científica sobre o Modelo Transteórico de Mudança de Comportamento relacionados ao consumo de álcool. Foram consultadas as bases de dados Scopus, PubMed, PsycINFO, PepsiCo e Lilacs, utilizando os descritores transtheoretical model, transtheoretical approach, stages of change, processes of change e cycle of change cruzado com o descritor alcoholism, no período de dez anos (2001 a 2011). Principais resultados: A maioria das pesquisas encontradas utilizavam métodos longitudinais e quantitativos, além de uma prevalência no uso dos questionários Readiness to Change Questionnaire e University of Rhode Island Change Assessment utilizados na mensuração do Modelo Transteórico. Os resultados indicaram que outras variáveis podem influenciar o comportamento do indivíduo em relação à sua fase de mudança de comportamento e identificou problemas relacionados ao uso de álcool em pacientes que procuravam tratamento para outras condições de saúde. Esta constatação reforça a necessidade de práticas de triagens para a prevenção dos agravos relacionados ao uso de álcool. Implicações: $\mathrm{O}$ modelo Transteórico é importante no processo de mudança de comportamento, uma vez que permite a identificação dos estágios e a escolha de intervenções mais adequadas ao estágio do paciente, além de evitar que esforços sejam feitos na direção contrária à necessidade do usuário. Conclusão: Ressalta-se a necessidade de mais estudos na área, especialmente em relação às práticas de profissionais de saúde.

Palavras-chave: Modelo Transteórico; estágios de mudança; alcoolismo; revisão sistemática 


\section{INTRODUCTION}

Alcohol consumption has been increasingly studied worldwide due to its social and economic impact, and the disorders related to alcohol use are among the most common substance abuse disorders (Abou-Saleh, 2006). According to the DSM-5, alcohol use disorder is defined as a problematic pattern of alcohol use leading to clinically significant impairment or distress, through the manifestation of at least two of the following symptoms, occurring within a 12-month period: tolerance, withdrawal, persistent desire or unsatisfactory effort for controlling its use; spending excessive time with consumption or consumed in larger amounts than it was intended; reduction in social, occupational or recreational activities due to such consumption; greater time spent in activities necessary to obtain alcohol, use alcohol, or recover from its effects; presence of craving or urge to use alcohol; recurrent alcohol use resulting in a failure to fulfil major role obligations at work, school, or home; continued alcohol use despite having persistent or recurrent social or interpersonal problems caused or exacerbated by the effects of alcohol; recurrent alcohol use in situations in which it is physically hazardous; and continued alcohol use despite knowledge of having a persistent or recurrent physical or psychological problem that is likely to have been caused or exacerbated by alcohol. (APA, 2013).

Epidemiological studies indicate that alcohol abuse causes significant morbidity and problems that are directly or indirectly related to important economic losses worldwide (Gallassi, Alvarenga, Andrade, \& Couttolenc, 2008). Thus, alcoholism is considered a public health problem throughout the world because of the well accepted and tested link between consumption and social grievances that flow from or are reinforced by it, such as economic losses, domestic violence, traffic accidents and crime. That is why alcohol abuse ranks among the five most disabling diseases around the world, and is the second leading cause of death related to substance use (Brasil, 2004).

This health problem has aroused the society concern and stressed the need to invest in studies that show effective methods for the treatment of alcoholism, taking into account the intrinsic factors that make some people change their addictive behaviour while others approach different treatments (Szupszynski \& Oliveira, 2008a). When considering the intrinsic factors of the individuals who need treatment for addiction much has been said about the readiness to change as an important factor that affects the individual's performance and adherence to treatment (Miller \& Rollnick, 2001). 
The Transtheoretical Model of Behavior Change (TTM), as described by Prochaska and DiClemente in 1979, is based on the premise that behavioural change takes place in stages, through which individuals undergo several levels of readiness to change (Szupszynski \& Oliveira, 2008b). The authors sought mainly to understand how and why people change either with the help of a therapist or by themselves. This paper also investigated different stages of change and found that they generally occur in a standardised manner and cross over a set of steps (Miller \& Rollnick, 2001). The TTM is based on the idea that change essentially depends on the person's consciousness about the need for change and that she or he must cope with the problem. It also requires personal commitment and mobilization that occur in a step-by-step fashion over time. This model consists of five steps, aims to seek healthy habits, and is often applied to addictive behaviours (Bittencourt, 2009).

In the first stage, known as pre-contemplation, there is no intention of changing because most individuals are unaware that their use of alcohol represents a problem (Calheiros, Andretta, \& Oliveira, 2006). The second stage, contemplation, is characterized by the ambivalence of individuals. They consider the implications which that change will entail for themselves and for the lives of people around them (Szupszynski \& Oliveira, 2008a). The third stage is the preparation phase in which the decision to change is made, but the individual has no strategies to put it into practice. The fourth stage is action, where strategies to change are put into practice (Calheiros, Andretta, \& Oliveira, 2006).

The last phase is maintenance, in which the subjects' change of lifestyle is effective. Then it is up to the person to maintain change over time, hence the importance of follow-up and care to prevent relapse (Szupszynski \& Oliveira, 2008a). In this model, relapse is considered a dynamic and nonlinear stage, in which a person can be in the maintenance phase and yet have a relapse causing him or her to go back to earlier stages (Barletta, 2010; Calheiros, Andretta, \& Oliveira, 2006).

In order to broaden and deepen the knowledge produced about this issue, we conducted a systematic review of scientific literature on the Transtheoretical Model of Behaviour Change related to drinking and alcohol dependence so as to assess and analyse the published literature in the area (Witter, 2005). The aims include (1) to further investigate if the transtheoretical model is used as an auxiliary instrument to the evaluation of readiness to change, (2) the most effective and suitable treatment methods for alcohol users in different contexts and (3) to evaluate the association between the transtheoretical model and other variables that may influence the treatment outcomes. 


\section{METHODS AND PROCEDURES}

\section{Search strategies}

Five databases were searched: LILACS, PsycINFO, PubMed, Scopus and Pepsic. The following search descriptors were used: "Stages of Change" "Cycle of Change", "Processes of Change", "Transtheoretical Approach", "Transtheoretical Model", which were crossed with the term "alcoholism" using the Boolean operator "AND".

\section{Inclusion criteria}

We used the following inclusion criteria: (1) Using the Transtheoretical Model of Behaviour Change from Prochaska \& DiClemente, (2) Having been published in Portuguese, English or Spanish, (3) Being an article with empirical data, (4) Having been published in the period between 2001 and 2011. We excluded (1) systematic or theoretical review articles, dissertations, thesis and book chapters and (2) articles published in the period before 2001.

The end result consisted of 92 abstracts, which were transcribed into a database, in which duplicate articles were crossed out (31), resulting in a total of 61 abstracts. After screening these abstracts, those which did not describe clearly the relationship between TTM and alcohol consumption, and those which did not provide the full text, were excluded altogether (35 articles). Thus, the final sample was composed of 26 full text articles.

\section{RESULTS}

\section{a) Bibliometric indicators}

With regard to the bibliometric indicators, authors, year of publication, journal, keywords, language and country of study were discriminated. As to the authorship of articles, only two were written by a single author, and the remaining 24 by multiple authors, with a maximum of nine authors. The triple-authored articles were 
the most common $(n=8)$. Arthur Blume, Karen B. Schmaling, Alan Marlatt and Nick Heather were authors of two articles. The other authors were found in only one article. All articles were published in English, except one, published in Spanish. The description of the journals that published the articles is presented in Table 1.

Table 1

Frequency of Published Articles

\begin{tabular}{ll}
\hline Title of journals & Fr \\
\hline Addictive Behaviors & 7 \\
Psychology of Addictive Behaviors & 3 \\
Addiction & 2 \\
European Addiction Research & 2 \\
Alcohol and Alcoholism & 2 \\
Acta Psychiatrica Scandinavica & 1 \\
Journal of American College Health & 1 \\
Journal of Substance Abuse Treatment & 1 \\
Health Education and Behaviour & 1 \\
Revista Brasileira de Psiquiatria & 1 \\
São Paulo Medical Journal & 1 \\
Community mental Health Journal & 1 \\
Journal of Critical Care & 1 \\
Adicciones & 1 \\
Drug and Alcohol Dependence & 1 \\
Journal of Studies on Alcohol and Drugs & 1 \\
Alcoholism: Clinical and Experimental Research & 1 \\
Journal of Studies on Alcohol & 1 \\
\hline Total & 1 \\
\hline
\end{tabular}

The keywords for the TTM are listed in descending order according to the number of citations: Motivation / Motivación (7), Stages of change (6), Transtheoretical model (4), Readiness (1), Transtheoretical (2), Readiness to change (1), Self-efficacy (2). The following were cited only once: Transtheoretical Model Treatment, Lifestyle change, Processes of change, Stage transitions, Openness to change.

With regard to alcohol, the most frequently keywords retrieved were Alcohol and Alcoholism, with six and four quotations respectively. Substance abuse and Alcohol consumption were cited two times. The expressions such as Dissonant addiction, Prenatal alcohol use, Alcohol drinking, Recidivist drink drivers, Alcohol problems, Drug addiction, Hazardous drinking, Drinking behaviour, Alcohol intoxication were quoted only once.

The country with the largest number of studies was the United States $(n=14)$, followed by Brazil, Australia and England, with two studies each. The others had only one study, namely, Sweden, Germany and Spain and three articles did not specify the search location. 


\section{b) Methodological aspects}

The following methodological aspects were analysed: (1) design, (2) instruments, (3) target population, (4) results. Of the 26 analysed articles, 15 used a longitudinal design, and the remaining 11 papers used a cross-sectional one. Quantitative methodology was used for all data analysis.

As for the target population, six papers used a sample of patients in treatment for alcohol abuse or alcohol addiction, and six referred to patients with alcohol abuse or alcohol dependence who were not in treatment; four papers investigated patients in health care services for treatment for various reasons, although they were screened as harmful or addicted users of alcohol; three articles investigated a sample of patients with psychiatric disorders who had the alcohol abuse or alcohol dependence as a co morbidity; two were conducted among college students. Specifically, the study of Chang, McNamara, Wilkins-Haug and Orav (2007) investigated pregnant users of alcohol; Share, Mark, McCrady and Epstein (2004) evaluated women in stable relationships in outpatient treatment for use of alcohol. Three other studies evaluated specific samples, such as drivers relapse in traffic problems due to alcohol use (Freeman et al., 2005); war veterans who were alcohol abusers or dependent (Copeland, Blow, \& Barry, 2003); and alcoholics divided into two groups: one in outpatient treatment specifically for alcohol, and the other for gastroenterological problems (Figlie et al., 2005).The instruments used to measure the use of alcohol and TTM related variables are listed in Tables 2 and 3.

Table 2

Frequency of Instruments Relating to Standard Alcohol found in the Analysed Articles

\begin{tabular}{ll}
\hline Title of Instruments & Fr \\
\hline Alcohol Use Disorders Identification Test (AUDIT) & 7 \\
Time-line Followback (TLFB); & 7 \\
Structured Clinical Interview for DSM Disorders (SCID) & 5 \\
Addiction Severity Index (ASI) & 4 \\
WHO's Composite International Diagnostic Interview & 2 \\
CAGE & 2 \\
Steady Pattern Chart (SP) from the Comprehensive Drinker Profile & 2 \\
'Form 90I' (DDD) (PDA) & 2 \\
Short-Form Alcohol Dependence Data Questionnaire (SADD) & 1 \\
Luebeck Alcohol dependence and abuse Screening Test (LAST) & 1 \\
Daily Drinking Questionnaire & 1 \\
13-item Campus Alcohol Survey (CAS) & 1 \\
Alcohol Consumption Questionnaire (ACQ) & 1 \\
Alcohol Dependence Scale (ADS) & 1 \\
Leeds Dependence Questionnaire (LDQ) & 1 \\
\hline
\end{tabular}


Table 3

Frequency of Instruments Relating to the Transtheoretical Model of Behavior Change found in the Analysed Articles

\begin{tabular}{ll}
\hline Title of Instruments & Fr \\
\hline Readiness to Change Questionnaire (RTCQ) & 11 \\
University of Rhode Island Change Assessment scale (URICA) & 7 \\
Stages of Change Readiness and Treatment Eagerness Scale (SOCRATES) & 5 \\
Processes of Change Survey (POC) & 4 \\
10-rung contemplation ladder & 1 \\
Readiness to Change Algorithm (RCA) & 1 \\
Stages of Change for Drink Driving Questionnaire (DRDV) & 1 \\
Unspecified & 4 \\
\hline
\end{tabular}

Regarding the measurement of alcohol use, we found a widespread use of the Alcohol Use Disorders Identification Test (AUDIT) (Babor, Higgins-Biddle, Saunders, \& Monteiro, 2003) and Timeline Follow-Back (TLFB) Interview (Sobell \& Sobell, 1992), both used in seven papers. The third instrument was the Structured Clinical Interview for DSM Disorders (SCID) (Spitzer, Williams, Gibbon, \& First, 1990) used in five articles. In order to measure the TTM, the highlights were the Readiness to Change Questionnaire (RTCQ) developed by Rollnick, Heather, Gold, and Hall (2006) as the most cited tool in research $(n=11)$, followed by the University of Rhode Island Change Assessment Scale (URICA) ( $\mathrm{n}=7)$, built by McConnaughy, Prochaska and Velicer, (1983).

Considering the results of the analysed articles, they were categorised into three categories according to its aims: (1) to evaluate the participants' stages of change; (2) evaluation of the stages of change influence on alcohol consumption; (3) relationship between the stages of change and other variables.

Category one included three papers that found that individuals on the action stage consume less alcohol (Chang et al., 2007) and used more behavioural change strategies than the ones on the pre-contemplation stage (Finnell, 2003). Besides, the majority of individuals who sought treatment for other health conditions were on the pre-contemplation stage compared to individuals who sought treatment for alcohol consumption that were on the contemplation, action or maintenance stages (Figlie et al., 2005).

Category two was composed of 16 articles whose main outcomes are described below: Oliveira Júnior and Malbergier (2003), Heesch, Velasquez and Von Sternberg (2005) found that people in stages from the preparation phase are more willing to change and respond better, in less time, and are more engaged to the treatment and the behaviour change (Copeland, 2003; Heather, Hönekopp, \& Smailes, 2009). They are also more committed and have more positive expectations regarding abstinence 
and more negative expectations related to alcohol consumption (Blanchard, Morgenstern, Morgan, Labouvie, \& Bux, 2003; Leontieva et al., 2005; Share et al., 2004) and their behaviour changes regarding alcohol consumption tend to improve through the stages of change (Kahler, 2001). On the other hand, Callaghan, Taylor and Cunningham's (2007) research did not find any significant differences on the behaviour change related to alcohol use among individuals on the pre-contemplation or contemplation stages and those on the preparation or action phases.

The patients who were on the contemplation stage had more severe alcohol use than the other participants (Zhang, Harmon, Werkner, \& McCormick, 2004) and the ones on the action stage consumed less alcohol (Share et al., 2004), had more chances to reduce this consumption, the risk behaviours associated to this consumption and the dependence symptoms when compared to the participants on the pre-contemplation stages. These findings may indicate that the stages of change may be predictors of alcohol consumption (Leontieva et al., 2005). However, Zhang, Harmon, Werkner and McCormick (2004) did not identify any SOCRATES subscale as a predictor of the alcohol use severity.

Walton et al. (2008) assessed participants in the emergency room and found that the most change willing were the ones who had consumed more alcohol during the last week, had more heavy alcohol use episodes on the last month, had more negative consequences linked to this use and attributed their injuries to the alcohol consumption. Likewise, Freeman et al., (2005) found that drivers who used to drive drunk were on the contemplation stage to stop the alcohol use, but on the action stage to leave the habit of drunk driving. The ones who were on the contemplation stage had higher levels of alcohol consumption while the ones on the pre-contemplation stage had lower levels, indicating that the harms associated to alcohol use may be a source of motivation for behaviour change. In the same direction, Heather, Adamson, Raistrick and Slegg (2010) found that individuals with greater harms related to alcohol use chose treatments that had the abstinence as the primary goal. Moreover, the majority of people who chose this kind of treatment were on the action stage while people on the other stages used to choose other forms of treatment.

Bingham et al. (2010) found that intervention strategies based on TTM increases the motivation for behaviour change regarding the alcohol use. Stotts, Schmitz and Grabowski (2003) stated that alcohol and tobacco dependents with more motivation to stop drinking and less motivation to stop smoking were more engaged to the treatment when compared to people who had high motivation to stop both substances, followed by the ones who had low motivation to stop drinking and smoking, indicating that focusing on the abstinence of more than one substance at the same time may be overwhelming for the people who want to stop their substance use. 
On category three were included seven papers that are described below according to the variables they relate to:

Blume, Schmaling and Marlatt (2005) related cognitive function with the stages of change and found that participants with less alcohol consumption and less verbal memory were on the pre-contemplation phase, while the ones diagnosed as alcohol dependents and with a higher score of verbal memory were on the contemplation stage. Also, the dependent participants related more recent behaviour changes than the alcohol abusers.

Other studies in this category evaluated the association between stages of change and psychiatric disorders. Blume, Schmaling and Marlatt (2001) research showed that the depressive symptoms of alcohol abusers were negatively related to the pre-contemplation and contemplation stages. A similar study with a sample of students (Smith \& Tran, 2007) found that the ones with higher levels of anxiety and depression were more conscious and ready to change their alcohol related behaviours. Likewise, Grothues et al. (2005) also showed that individuals with some co-morbidity to the alcohol problems were on the contemplation stage, while the individuals with no co-morbidity were on the pre-contemplation stage.

Baker et al. (2002) did not demonstrate any significant correlation between the stages of change and mental health disorders among psychiatric patients that use alcohol. Another research (Sánchez-Hervás, Gradolí, Bou, Gurrea, \& Gallús, 2002) demonstrated that psychopathological symptoms positively influence the cognitive change processes and the time that the substance has been used or abused hampers the acquisition of behavioural change strategies.

Ekendahl (2007) demonstrated that less change willing individuals are less alcohol dependents, have lower treatment demands, lower motivation and less future and lifestyle changes perspectives than more change willing individuals.

\section{DISCUSSION}

The analysis of the literature in the area allows for the construction of an appropriate and updated sound theoretical base that guides the practice and teaching areas, bringing about the redefinition of more relevant strategies, and ensuring the full exercise of research as well as the exchange of ideas and the dissemination of results up to date (Witter, 2005).

However, it is emphasised that the conclusions arising from this review should be understood in the range of its framework. When investigating a specific set of sources, within a given period of time, favouring only the scientific information 
published in peer-reviewed journals can produce bias in reviews. As they were published, the articles under analysis had a greater chance to include only information relating to significant results that support the main hypothesis of the study. Despite these limitations, the systematisation of the process allows the possibility of this study to be replicated taking into consideration other temporal boundaries to enable comparisons with the current findings.

As for authorship, we found an increase in the number of multiple authors, indicating a tendency towards studies carried out by research teams at the expense of single authorship. However, we could not identify any author or research group that excels in studies on the subject, since the largest number of publications by the same author comes down to two. It is also noteworthy that there was not a linear increase in the number of publications over the years, given the existence of some peaks of publications occurring in the years 2003, 2005 and 2007. However, only the years of 2006 and 2011 have shown no publication found, which denotes the persistence of the subject over time as the focus of interest for research related to alcohol use. One factor that hindered this research relates to the key words used to search for TTM, since there is no standard descriptor, what may cause the omission of articles that deal with the issue but cannot be identified due to this shortcoming.

Most studies used a longitudinal design, which is a more adequate methodology to evaluate readiness to change, once this is a construct that may change through time and might be misunderstood with a cross-sectional design. This finding also might indicate an increase of funding by research agencies, since this type of study involves major financial and logistical costs. Another aspect related to design is concerned with the quantitative analysis of the data used in all studies. This may have occurred due to the subject of this review that investigates the application of TTM to the use of alcohol, which leads to studies of evidence-based interventions. The absence of qualitative research on this subject may indicate a further consolidation of this model. Since there are already standardised and validated instruments to quantify these concepts, there is no need for further exploratory research.

With respect to the instruments used to measure the stages of change, it was observed that there was a standardisation of instruments, as more than half of the studies used two previously validated tools. On the one hand, The Readiness to Change Questionnaire (RTCQ) is an instrument with 12 items that categorises people who are not seeking treatment according to the following stages of change: pre-contemplation, contemplation and action based on how patients feel about their alcohol use at present (Rollnick et al., 1992). On the other hand, the University of Rhode Island Change Assessment - URICA (McConnaughy et al., 1983) draws on the stages of change in TTM and it is a scale that assesses the motivational stages 
of individuals by means of four subscales corresponding to the stages of change model. In Brazil, there is a URICA validated version (Szupszynski \& Oliveira, 2008b).

In the analysis of the participants of the study, it was found that none investigated the perception and practice of health professionals about the importance of assessing patients' stages of change by initiating treatment at a health clinic. Since these are key elements to contribute to the implementation of prevention practises, promotion or treatment of health conditions, it is important that their training involves content which relates to the intervention features found in the context in which they are inserted (Barros \& Pillon, 2006).

Another important point is the identification of alcohol-related problems in patients seeking treatment for other health conditions, highlighting the need for screening practises for injury prevention in health related to alcohol use. As noted in the literature, patients who are not screened for their alcohol problems tend to drink longer and have a worsening of their health condition (Figlie et al., 2005).

One possible reason for this neglect on the screening for alcohol-related problems may be the fact that alcohol is a legal drug widely accepted in the social environment, being present in people's daily life and used mostly for entertainment. However, this permissive perception may prevent the harmful abuse of alcohol from detection and treatment and increase the number of years of grievance. Sánchez-Hervás et al., (2002), in a study of three groups of drug addicted participants (alcohol, heroin and cocaine), found that the group of alcohol dependents had a longer consumption and greater number of years of abuse, followed by the group of heroin and cocaine respectively.

The conceptual model (TTM) assumes that behavioural changes result from the understanding of health-related attitudes and beliefs that motivate the individuals to change their behaviour. Therefore, individuals who abuse alcohol can best benefit from an intervention, due to the awareness of the impact of alcohol intake in their daily life, compared with those who drink less but do not face as tightly to the damage caused by alcohol (Bingham, Barretto, Walton, Bryant, Shope, \& Raghunathan, 2010).

There is a need for studies to identify possible differences in motivation to change addictive behaviour among alcohol dependents who sought treatment and those who did not seek it. The failure to compare these groups could cause bias in the results of the studies, since, when investigating a sample of people who sought treatment on their own, it is expected that these people are already in advanced stages of the model and may recognise the need to seek help, thus showing a greater commitment to treatment. These considerations are in line with the results of Heather, Adamson, Raistrick and Slegg's (2010) research in which participants who preferred an abstinence-based treatment were more engaged in the conduct of the action stage of the TTM than the participants who had an affinity for other types of treatment not focused on abstinence. 
In the study by Walton et al. (2008), 53.4\% of patients admitted to the emergency room after suffering some kind of accident and who used alcohol were at the precontemplation stage, or did not see any problem in their consumption of alcohol and had no intention of changing their behaviour. Thus, it confirms the need to propose interventions for those patients seeking treatment for other conditions but that may well make hazardous alcohol use.

In relation to the objectives of the studies, it was observed that most of them were included in the category that investigates the stages of change as a mediator of treatment outcome. As for the results of the studies, as noted in the research of Williams, Horton, Samet and Saitz (2007), it was observed that there is an association between the number of problems related to alcohol consumption and its negative consequences on the motivation to reduce its use. That is, the more the patients perceived injuries related to alcohol use, the more they felt motivated to change their behaviour.

The systematisation of the literature review process allows this study to be replicated in the future, relying on other delimitations, allowing the results to be compared, while identifying gaps in the literature that serve as drivers of new studies and enable the advancement of scientific knowledge. However, it is worth noting that, despite having significant results, this review has some limitations. Given the fact that we investigated a limited set of databases, selection bias may have occurred. Moreover, the strategy used for data collection may have limited the universe surveyed, since studies that did not address the issue as one of its main topics or did not use the investigated descriptors were excluded from this review.

\section{Clinical implications and future research}

Despite the absence of an exponential growth of literature on the subject of this review, the findings suggest that TTM is extremely important in the process of behaviour change, since it allows the identification of the stages and the better adapted interventions based on the patient's stage. Thus, it avoids making efforts in the opposite direction to what is demanded by the patient. Recognising that each individual has its cycle of development and that it influences their attitudes and behaviours, their individuality is also recognised, applying interventions which, in fact, will reach its target population.

While the importance of this assessment is stressed by the process of dealing with problems related to alcohol consumption, it becomes clear that the theoretical framework on this subject still needs to be developed so as to investigate the practical application of this assessment by health professionals as well as their perception of it. Thus, further research should be directed to the use of the patient's 
stage of change for action planning aimed specially at them, since most of this review's studies focused on assessing the stage of change as a mediator of treatment outcome, but did not use them to better target the treatment. It is expected that the results could spark an interest in the research area as well as to generate grants for programs designed for risky users of alcohol.

\section{AKNOWLEDGEMENTS}

We express our appreciation to the University’s Graduate Program in Psychology for its unabridged support.

\section{REFERENCES}

Abou-Saleh, M. T. (2006). Substance use disorders: recent advances in treatment and models of care. Journal of Psychosomatic Research, 61, 305-310. doi:10.1016/j.jpsychores.2006.06.013

American Psychiatric Association. (2013).Diagnostic and statistical manual of mental disorders ( $5^{\text {th }}$ ed.). Washington, DC: American Psychiatric Association.

Babor, T. F., Higgins-Biddle, J. C., Saunders, J. B., \& Monteiro, M. G. (2003). AUDIT: The Alcohol Use Disorders Identification Test: Guidelines for use in Primary Care.(second edition). Geneva: World Health Organization.

Baker, A., Lewin, T., Reichler, H., Clancy, R., Carr, V., Garrett, R., ... Terry, M. (2002). Motivational interviewing among psychiatric in-patients with substance use disorders. Acta Psychiatrica Scandinavica, 106(3), 233-240. doi:10.1034/j.1600-0447.2002.01118.x

Barletta, J. B. (2010). Comportamento e crenças em saúde: Contribuições da psicologia para a medicina comportamental. Revista de Psicologia da IMED, 2(1), 307-317.

Barros, M. A. D., \& Pillon, S. C. (2006). Programa Saúde da Família: desafios e potencialidades frente ao uso de drogas. Revista Eletrônica de Enfermagem, 8(1), 144-149.

Bingham, C. R., Barretto, A. I., Walton, M. A., Bryant, C. M., Shope, J. T., \& Raghunathan, T. E. (2010). Efficacy of a web-based, tailored, alcohol prevention/intervention program for college students: Initial findings. Journal of American College Health, 58(4), 349-356. doi:10.1080/07448480903501178

Bittencourt, S. A. (2009). Motivação para a mudança: Adaptação e validação da escala urica (University of Rhode Island Change Assessment) para o comportamento de comer compulsivo ( $\mathrm{PhD}$ Thesis). PUCRS, Porto Alegre.

Blanchard, K. A., Morgenstern, J., Morgan, T. J., Labouvie, E., \& Bux, D. A. (2003). Motivational subtypes and continuous measures of readiness for change: Concurrent and predictive validity. Psychology of Addictive Behaviors, 17(1), 56-65. doi:10.1037/0893-164X.17.1.56

Blume, A. W., Schmaling, K. B., \& Marlatt, G. A. (2001). Motivating drinking behavior change: Depressive symptoms may not be noxious. Addictive Behaviors, 26(2), 267-272. doi: 10.1016/ 
S0306-4603(00)00087Blume, A. W., Schmaling, K. B., \& Marlatt, G. A. (2005). Memory, executive cognitive function, and readiness to change drinking behavior. Addictive Behaviors, 30(2), 301-314. doi:10.1016/j.addbeh.2004.05.019

Brasil. Ministério da Saúde Secretaria de Atenção a Saúde. Departamento de Ações Programáticas Estratégicas. (2004) Álcool e redução de danos: uma abordagem inovadora para países em transição (p. 43). Brasília: Ministério da Saúde.

Calheiros, P., Andretta, I. E., \& Oliveira, M. (2006). Avaliação da motivação para mudança nos comportamentos adictivos. In B. Werlang \& M. S. Oliveira, Temas em Psicologia Clínica (pp. 115-124). São Paulo: Casa do Psicólogo.

Callaghan, R. C., Taylor, L., \& Cunningham, J. A. (2007). Does progressive stage transition mean getting better? A test of the Transtheoretical Model in alcoholism recovery. Addiction, 102(10), 1588-1596. doi:10.1111/j.1360-0443.2007.01934.x

Chang, G., McNamara, T., Wilkins-Haug, L., \& Orav, J. (2007). Stages of change and prenatal alcohol use. Journal of Substance Abuse Treatment, 32(1), 105-109. doi:10.1016/j.jsat.2006.07.003

Copeland, L. A., Blow, F. C., \& Barry, K. L. (2003). Health care utilization by older alcohol-using veterans: Effects of a brief intervention to reduce at-risk drinking. Health Education and Behavior, 30(3), 305-321. doi:10.1177/1090198103030003006

Ekendahl, M. (2007). Will and skill - An exploratory study of substance abusers' attitudes towards lifestyle change. European Addiction Research, 13(3), 148-155. doi:10.1159/000101551

Figlie, N. B., Dunn, J., Gomes, L. C. S., Turisco, J., Payá, R., \& Laranjeira, R. (2005). Motivation to change drinking behavior: The differences between alcohol users from an outpatient gastroenterology clinic and a specialist alcohol treatment service. Sao Paulo Medical Journal, 123(5), 223-228. doi:10.1590/S1516-31802005000500005

Finnell, D. S. (2003). Addictions services: Use of the Transtheoretical Model for Individuals with CoOccurring Disorders. Community Mental Health Journal, 39(1), 3-15. doi:10.1023/A:1021273206004

Freeman, J., Liossis, P., Schonfeld, C., Sheehan, M., Siskind, V., \& Watson, B. (2005). Self-reported motivations to change and self-efficacy levels for a group of recidivist drink drivers. Addictive Behaviors, 30(6),1230-1235. doi:10.1016/j.addbeh.2004.10.007

Gallassi, A. D., Alvarenga, P. G. D., Andrade, A. G. D., \& Couttolenc, B. F. (2008). Custos dos problemas causados pelo abuso do álcool. Revista de Psiquiatria Clínica, 35 (Supl I), 25-30. doi:10.1590/ S0101-60832008000700007

Grothues, J., Bischof, G., Reinhardt, S., Hapke, U., Meyer, C., John, U., Rumpf, H. J. (2005). Intention to change drinking behaviour in general practice patients with problematic drinking and comorbid depression or anxiety. Alcohol and Alcoholism, 40(5), 394-400. doi:10.1093/alcalc/agh182

Heather, N., Adamson, S. J., Raistrick, D., \& Slegg, G. P. (2010). Initial preference for drinking goal in the treatment of alcohol problems: I. Baseline differences between abstinence and nonabstinence groups. Alcohol and Alcoholism, 45(2), 128-135. doi:10.1093/alcalc/agp096

Heather, N., Hönekopp, J., \& Smailes, D. (2009). Progressive stage transition does mean getting better: A further test of the Transtheoretical Model in recovery from alcohol problems. Addiction, 104(6), 949-958. doi:10.1111/j.1360-0443.2009.02578.x

Heesch, K. C., Velasquez, M. M., \& Von Sternberg, K. (2005). Readiness for mental health treatment and for changing alcohol use in patients with comorbid psychiatric and alcohol disorders: Are they congruent? Addictive Behaviors, 30(3), 531-543. doi:10.1016/j.addbeh.2004.08.003

Kahler, C. W. (2001). Generation and recall of alcohol-related information in excessive drinkers: Relation to problem severity, outcome expectancies, and stage of change. Psychology of Addictive Behaviors, 15(2), 109-117. doi:10.1037//0893-164X.15.2.109 
Leontieva, L., Horn, K., Haque, A., Helmkamp, J., Ehrlich, P., \& Williams, J. (2005). Readiness to change problematic drinking assessed in the emergency department as a predictor of change. Journal of Critical Care, 20(3), 251-256. doi:10.1016/j.jcrc.2005.05.009

McConnaughy, E. A., Prochaska, J. O., \& Velicer, W. E. (1983). Stages of change in psychotherapy: measurement and sample profiles. Psychotherapy: Theory, Research and Practice, 20(3), 368375. doi:10.1037/h0090198

Miller, W. R., \& Rollnick, S. (2001). Entrevista motivacional: Preparando as pessoas para a mudança de comportamentos adictivos. Porto Alegre, RS: Artmed.

Oliveira Júnior, H. P., \& Malbergier, A. (2003). Assessment of motivation for treatment in alcohol dependent patients who sought treatment at a specialized medical service. Revista Brasileira de Psiquiatria, 25(1), 5-10. doi:10.1590/S1516-44462003000100003

Rollnick, S., Heather, N., Gold, R., \& Hall, W. (1992). Development of a short Readiness to Change Questionnaire for use in brief opportunistic brief interventions. British Journal on Addiction, 87, 745-754. doi:10.1111/j.1360-0443.1992.tb02720.x

Sánchez-Hervás, E., Gradolí, T. V., Bou, M. N., Gurrea, O. R., \& Gallús, M. E. (2002). Procesos de cambio en conductas adictivas: Influencia de variables psicopatológicas y de consumo. Addiciones, 14(3), 337-344.

Share, D., McCrady, B., \& Epstein, E. (2004). Stage of change and decisional balance for women seeking alcohol treatment. Addictive Behaviors, 29(3), 525-535. doi:10.1016/j.addbeh.2003.08.022

Smith, J. P., \& Tran, G. Q. (2007). Does negative affect increase change readiness among college hazardous drinkers? Addictive Behaviors, 32(10), 2281-2285. doi: 10.1016/j.addbeh.2007.01.019

Sobell, L. C., \& Sobell, M. B. (1992). Timeline Follow-back: A technique for assessing self-reported alcohol consumption. In J. P. Allen, \& R. Z. Litten (Eds.), Measuring alcohol consumption: Psychosocial and biochemical methods (pp. 41-72). Totowa: Humana Press.

Spitzer, R. L., Williams, J. B. W., Gibbon, M., \& First, M. B. (1990). Structured clinical interview for DSM-III-R - patient edition (SCID-P). Washington DC: American Psychiatric Press.

Stotts, A. L., Schmitz, J. M., \& Grabowski, J. (2003). Concurrent treatment for alcohol and tobacco dependence: Are patients ready to quit both? Drug and Alcohol Dependence, 69(1), 1-7. doi:10.1016/S0376-8716(02)00227-2

Szupszynski, K. P. D. R., \& Oliveira, M. S. (2008a). O Modelo Transteórico no tratamento da dependência química. Psicologia: Teoria e Prática, 10(1), 162-173.

Szupszynski, K. P. D. R., \& Oliveira, M. S. (2008b). Adaptação Brasileira da University of Rhode Island Change Assessment (URICA) para usuários de substâncias ilícitas. PsicoUSF, 13 (1), 31-39. doi:10.1590/S1413-82712008000100005.

Walton, M. A., Goldstein, A. L., Chermack, S. T., McCammon, R. J., Cunningham, R. M., Barry, K. L., \& Blow, F. C. (2008). Brief alcohol intervention in the emergency department: Moderators of effectiveness. Journal of Studies on Alcohol and Drugs, 69(4), 550-560.

Williams, E. C., Horton, N. J., Samet, J. H., \& Saitz, R. (2007). Do brief measures of readiness to change predict alcohol consumption and consequences in primary care patients with unhealthy alcohol use? Alcoholism: Clinical and Experimental Research, 31(3), 428-435. doi:10.1111/j.15300277.2006.00324.x

Witter, G. P. (2005). Leitura no Reading Research Quarterly. In G. P. Witter (Org.). Metaciência e Psicologia (pp. 137-154). Campinas, SP: Alínea.

Zhang, A. Y., Harmon, J. A., Werkner, J., \& McCormick, R. A. (2004). Impacts of motivation for change on the severity of alcohol use by patients with severe and persistent mental illness. Journal of Studies on Alcohol, 65(3), 392-397. 